\title{
Study of Antenatal Care Completion Determinant Factors in Kedougou Health District (Senegal)
}

\author{
Babacar Biaye1, David Ngom², Moussa Ndiaye², Fode Danfakha², Omar Gassama1, \\ Abdoul Aziz Diouf ${ }^{1}$, Adama Faye ${ }^{3}$, Dembo Guirassi' ${ }^{4}$, Alassane Diouf ${ }^{1}$, Jean Charles Moreau' \\ ${ }^{1}$ Aristide Le Dantec Teaching Hospital, Dakar, Senegal \\ ${ }^{2}$ kedougou Health District, Kedougou, Senegal \\ ${ }^{3}$ Public Health Department, Cheikh Anta Diop University, Dakar, Senegal \\ ${ }^{4}$ Reproductive Health Department/Health Ministry, Dakar, Senegal \\ Email: drbabacarbiaye@yahoo.fr
}

How to cite this paper: Biaye, B., Ngom, D., Ndiaye, M., Danfakha, F., Gassama, O., Diouf, A.A., Faye, A., Guirassi, D., Diouf, A. and Moreau, J.C. (2020) Study of Antenatal Care Completion Determinant Factors in Kedougou Health District (Senegal). Open Journal of Obstetrics and Gynecology, 10, 1449-1470.

https://doi.org/10.4236/ojog.2020.10100133

Received: July 25, 2020

Accepted: October 25, 2020

Published: October 28, 2020

Copyright $\odot 2020$ by author(s) and Scientific Research Publishing Inc. This work is licensed under the Creative Commons Attribution International License (CC BY 4.0).

http://creativecommons.org/licenses/by/4.0/

\begin{abstract}
Introduction: Maternal mortality is a public health problem of more concern to developing countries. As part of improving the maternofoetal prognosis during pregnancy and childbirth, it is essential to carry out regular follow-ups of pregnant women (FE) through antenatal consultations (ANC). In fact, the World Health Organization (WHO) recommends at least four ANC at regular intervals during pregnancy. In Senegal the completion rate varies greatly depending on the region. In the District of Kédougou it was $41 \%$ in 2017 (DHIS2). The national target was not achieved despite the interventions. Thus we studied the determinants of CPN completion in the health district of Kedougou in 2017. Method: The study is of a descriptive and analytical cross-sectional type and concerned a sample of 884 women who gave birth between October 2017 and September 2018. They were chosen by a sample whose distribution in the district was made according to the quota method while respecting the demographic weight of each area of responsibility of the District. Results: The results of our study showed that the average age of women was 24 years with an average number of pregnancies equal to 3 . The ANC completion rate at $37 \%$ was lower than the administrative data rate which was $41 \%$. The determinants with a statistically most significant link with the completion of ANC are respectively satisfaction with the care and quality of service, the level of information of women regarding PNC, marital status, affordability and distance from the location of the ANC. Conclusion: Increasing women's incomes, increasing communication about ANC, and bringing health services closer together are needed to improve the completion rate of antenatal care visits.
\end{abstract}




\section{Keywords}

Prenatal Consultation, Completion, Kédougou

\section{Introduction}

Maternal mortality is a public health concern mainly affecting developing countries.

In 2012, WHO estimated that among the 287,000 maternal deaths that occurred in 2010, 56\% were in sub-Saharan Africa and 29\% in South Asia [1].

In Senegal the maternal mortality rate is 392 per 100,000 live births, corresponding to a very high rate despite it slightly declined over the recent years [2].

To prevent complications that may arise during pregnancy and delivery, it is essential to carry out regular follow-ups of pregnant women (PW) through antenatal consultations (CPN). The World Health Organization (WHO) recommends at least four ANCs at regular intervals during pregnancy [1].

ANCs are medical care delivered to the woman during pregnancy that helps ensure that she and her newborn survive pregnancy and childbirth.

In Senegal, 93\% of pregnant women consulted a health professional during their most recent pregnancy [2]. However, the completion rate varies greatly by region.

In Kedougou, antenatal care indicators significantly increased between 2015 and 2016. The ANC completion rate moved from $15 \%$ to $41 \%$ [3]. This rate was estimated at $41 \%$ in Kedougou District in 2017 (DHIS2). The national objective was not achieved despite the interventions.

Against this backdrop, we conducted this study that aimed at determining the ANC completion rate in the Kedougou Health District in 2017 and the associated factors. In this way, we hope to contribute to the reduction of maternal and neonatal mortality through the identification of the ANC completion determinants in the Kedougou Health District in particular and in the region in general.

The objectives of this study are to:

- Describe the personal characteristics of reproductive age women;

- Describe the ANC accessibility factors among women of reproductive age;

- Describe the health structures-related determinants in Kedougou Health District;

- Estimate the rate of completion of ANC for women of reproductive age;

- Identify the factors associated with the ANC completion for women of reproductive age.

\section{Methodology}

We conducted a looking-forward cross-sectional descriptive and analytical study involving women who gave birth during the period range from October 2017 to 
September 2018 in the health district of Kedougou.

\section{$\square$ Sampling}

\section{+ Selection Criteria}

Were included:

- women who gave birth in the last 12 months prior to the survey (October 2017 and September 2018),

$\circ$ and having monitored in the district during the eight months of pregnancy.

+ Non-inclusion criteria:

We didn't include:

$\bigcirc$ any woman who didn't agree to give consent for the interview,

o or who were missing at the time of the survey.

+ Sample size calculation

To calculate the sample size we used the formula underneath:

$$
\begin{gathered}
\mathrm{n}=\mathfrak{E}^{2 \star} \mathrm{p}^{\star} \mathrm{q} / \mathrm{i}^{2} \text { with } \mathfrak{E}=1.96 ; \mathrm{p}=0.5 ; \mathrm{q}=1-\mathrm{p}=1-0.5=0.5 \mathrm{i}=0.05 \\
\mathrm{n}=(1.96)^{2 \star}\left(0.5^{\star} 0.5\right) /(0.05)^{2}
\end{gathered}
$$

$\mathrm{n}=384$, with the cluster effect, we multiplied this sample size (n) by 2 and we add $10 \%$ to it which finally gives a sample size of 845 . To facilitate the sample distribution while improving precision, we included 884 women.

+ Sampling method:

The entire district area of responsibility is included in the study. Each Service Delivery Point (SDP) was assigned a number of clusters proportional to the size of its population in the area it covers.

We randomly selected the clusters for each area and in each village or neighborhood (cluster). The bottle method was used to specify the direction to be followed by the interviewers.

Once the direction was determined, the first concession to be surveyed would be the second on the left. In each concession all women who meet the inclusion criteria will be surveyed. If the cluster size is not reached in a village, the interviewer will go to the nearest village until the cluster size is reached.

\section{$\square$ Data collection}

\section{+ Collection tools}

We used a questionnaire represented in three parts that focus on the variables of Kedougou Health District study

\section{+ Collection method}

A single day training session of the 13 interviewers and 6 supervisors was performed at the health center. The interviewers conducted individual interviews in the households after obtaining the women's consent to be interviewed.

+ Collected data

The survey questionnaire included various headings that allowed us to collect the following information:

- Personal characteristics data of the women surveyed: age, ethnicity, gender, parity, marital status, occupation of the woman and her 
spouse, education level and the number of ANC carried out;

- Data related to financial, geographical and socio-demographic accessibility;

- Data on factors related to health facilities, in particular: confidentiality, waiting time, and care during antenatal care.

\section{Data entry}

It is made on Epi info input mask. We have created an input template with the same variables found on the questionnaire. We entered the information collected on the model to obtain the database that we analyzed.

\section{$\square$ Data analysis}

It comprises two parts:

+ A descriptive part of the quantitative variables with the extremes, means and standard deviation and a description of the qualitative variables with their frequency and confidence interval.

+ An analytical part, where we used the Chi2 test and the Fisher test under their applicability conditions with a $\mathrm{p}$ threshold $<0.05$ to assess the existence of a link in the bivariate analysis and the OR different from 1 to assess the strength of this link.

\section{Ethical considerations}

We shared the study-related information with all participants. The free and informed consent of the participants was obtained prior to the administration of the questionnaire. The choice of not participating or to discontinue participation during the interview was respected. The anonymity of participants was respectfully guaranteed by the investigators.

\section{Results}

\subsection{Descriptive Study}

\section{+ Personal factors}

Overall we surveyed a number of 884 women with a mean age of 24 years and a standard deviation of 6.1 . The mode is 20 years. The majority of women $(59.84 \%)$ are under 25 years of age.

The average number of pregnancies for these women is 3 with a standard deviation of 1.95. The maximum number of pregnancies noted for a woman is 11 .

The average number of deliveries is 2 with a standard deviation of 1.68 . There are 318 primiparous, corresponding to $35.97 \%$ of the sample. Pauciparous ( 2 to 3 deliveries) and multiparous (4 deliveries) are respectively 348 and 98, representing respectively $39.37 \%$ and $11.08 \%$ of the sample. The large multiparous (more than 4 births) are 120, representing $13.58 \%$ of the sample. These results are summarized in Table 1.

\section{+ Socio-professional factors}

The Fulani (Peulh) ethnic group represents $61.54 \%$ of the sample, accounting for a total of 544, followed by Malinkés, 15.38\% (136); Bassaris and Soninkés $2.49 \%$ and $2.04 \%$ respectively (22 and 18 ). 
Table 1. Distribution of women surveyed according to personal factors in October 2017 in the Kedougou Health District.

\begin{tabular}{ccc}
\hline Personal factors & $\begin{array}{c}\text { Absolute Frequency } \\
(\mathrm{n}=884)\end{array}$ & $\begin{array}{c}\text { Relative } \\
\text { frequency (\%) }\end{array}$ \\
\hline Age group & 529 & $59.84 \%$ \\
Under 25 years & 355 & $40.16 \%$ \\
25 years and more & & \\
Parity & 318 & $35.97 \%$ \\
Primiparous & 348 & $39.37 \%$ \\
Pauciparous (2 to 3 deliveries) & 98 & $11.08 \%$ \\
Multiparous (4 deliveries) & 120 & $13.58 \%$ \\
Grand multiparity (more than deliveries) & & \\
Gestity & & $32.47 \%$ \\
1 pregnancy & 287 & $37.78 \%$ \\
2 to 3 pregnancies & 334 & $18.55 \%$ \\
4 to 5 pregnancies & 164 & $11.20 \%$ \\
6 pregnancies and more & 99 & \\
\hline
\end{tabular}

The number of educated women is 650 corresponding to $73.53 \%$ of the sample, of whom 452 have attended French schools. Only 217 of them, $24.55 \%$, have an income-generating activity.

The vast majority of women, $94.57 \%$, are married and $77.83 \%$ of spouses are educated. The majority of husbands, $80.43 \%$, have an income-generating activity (Table 2).

\section{+ Accessibility factors}

$\circ$ Geographic and financial accessibility

Among the respondent women, 586 representing $66.29 \%$ had a monthly income of less than 50,000 and 588 women, $66.52 \%$, considered the cost of ANC affordable.

The majority of women, $77.79 \%$, perform their ANC in a structure located less than $5 \mathrm{~km}$ from their place of residence. The most common means of transport are walking, car and motorcycle, used by $68.33 \%, 14.48 \%$ and $13.35 \%$ of women respectively (Table 3).

\section{- Socio-cultural accessibility}

For 535 women, representing $60.52 \%$ of the sample, the decision to do ANC is made by the husband. Only $29.98 \%$ of the women made the decision to have ANC themselves, and $5.77 \%$ of the cases were decided by the mother-in-law (Table 4).

The majority, accounting for $74.09 \%$, prefer a female provider, while only $4.19 \%$ prefer a male provider. 
Table 2. Respondent women distribution according to socio-professional characteristics in October 2018 in the district of Kedougou.

\begin{tabular}{|c|c|c|c|}
\hline $\begin{array}{c}\text { Socio-professional } \\
\text { characteristics }\end{array}$ & $\begin{array}{l}\text { Absolute frequency } \\
\qquad(\mathrm{n}=884)\end{array}$ & $\begin{array}{c}\text { Relative } \\
\text { frequency }(\%)\end{array}$ & $\begin{array}{c}\text { Confidence } \\
\text { interval (95\%) }\end{array}$ \\
\hline \multicolumn{4}{|l|}{ Ethny } \\
\hline Bassari & 22 & 2.49 & $1.65-3.74$ \\
\hline Bedik & 7 & 0.79 & $0.38-1.63$ \\
\hline Malinké & 136 & 15.38 & $13.16-17.91$ \\
\hline Peulh & 544 & 61.54 & $58.29-64.69$ \\
\hline Sérère & 16 & 1.81 & $1.12-2.92$ \\
\hline Soninké & 18 & 2.04 & $1.29-3.20$ \\
\hline Wolof & 26 & 2.94 & $2.01-4.27$ \\
\hline Other & 115 & 13.01 & $10.95-15.39$ \\
\hline \multicolumn{4}{|c|}{ Women's education model } \\
\hline Literacy & 22 & 2.49 & $2.25-5.07$ \\
\hline Coranic school & 6 & 0.68 & $0.42-2$ \\
\hline Arabic school & 170 & 19.23 & $22.92-29.67$ \\
\hline French school & 452 & 51.13 & $65.89-72.95$ \\
\hline Uneducated & 234 & 26.47 & \\
\hline \multicolumn{4}{|c|}{ Men's education model } \\
\hline Literacy & 18 & 2.03 & $1.69-4.16$ \\
\hline Coranic school & 202 & 22.85 & $23.6-34$ \\
\hline Arabic school & 7 & 0.80 & $0.5-2.12$ \\
\hline French school & 450 & 50.90 & $51.6-63$ \\
\hline Uneducated & 207 & 23.42 & $11.8-19.5$ \\
\hline \multicolumn{4}{|l|}{ Marital status } \\
\hline Married & 836 & 94.57 & $92.87-95.88$ \\
\hline Single & 47 & 5.32 & $4.02-7$ \\
\hline Widow & 1 & 0.11 & $0.02-0.64$ \\
\hline \multicolumn{4}{|l|}{ Women's occupation } \\
\hline Trader & 152 & 17.20 & $14.85-19.82$ \\
\hline Farmer & 42 & 4.75 & $3.53-6.36$ \\
\hline Public servant & 14 & 1.58 & $0.95-2.64$ \\
\hline Housekeeper & 611 & 69.12 & $65.99-72.08$ \\
\hline Gold digger & 9 & 1.02 & $0.54-1.92$ \\
\hline None & 56 & 6.63 & $4.91-8.14$ \\
\hline \multicolumn{4}{|l|}{ Men's occupation } \\
\hline Trader & 192 & 21.72 & $19.13-24.56$ \\
\hline Farmer & 150 & 16.97 & $14.64-19.58$ \\
\hline Breeder & 10 & 1.13 & $0.62-2.07$ \\
\hline Public servant & 91 & 10.29 & $8.46-12.47$ \\
\hline Gold digger & 170 & 19.23 & $16.77-21.96$ \\
\hline Worker & 248 & 28.05 & $25.19-31.11$ \\
\hline None & 23 & 2.60 & $1.74-3.87$ \\
\hline
\end{tabular}


Table 3. Distribution of women surveyed according to geographical and financial factors as of October 2017 in the Health District of Kédougou.

\begin{tabular}{|c|c|c|c|}
\hline $\begin{array}{c}\text { Geographical and } \\
\text { financial accessibility } \\
\text { factors }\end{array}$ & $\begin{array}{l}\text { Absolute frequency } \\
\qquad(\mathrm{n}=884)\end{array}$ & $\begin{array}{c}\text { Relative } \\
\text { frequency (\%) }\end{array}$ & $\begin{array}{c}\text { Confidence } \\
\text { interval (95\%) }\end{array}$ \\
\hline \multicolumn{4}{|l|}{ Mean income } \\
\hline Less than 47.000 Frs & 287 & 32.47 & $29.38-35.55$ \\
\hline $47.000-50.000$ Frs & 299 & 33.82 & $30.82-37.05$ \\
\hline $50.000-100.000$ Frs & 193 & 21.83 & $19.26-24.70$ \\
\hline More than 100.000 Frs & 105 & 11.88 & $9.92-14.19$ \\
\hline \multicolumn{4}{|l|}{ ANC cost } \\
\hline Very affordable & 156 & 17.75 & $15.36-20.41$ \\
\hline Affordable & 432 & 49.15 & $45.85-52.45$ \\
\hline slightly affordable & 202 & 22.98 & $20.32-25.88$ \\
\hline Unaffordable & 55 & 6.25 & $4.84-8.06$ \\
\hline Strongly not affordable & 34 & 3.87 & $2.78-5.36$ \\
\hline \multicolumn{4}{|l|}{ ANC venue } \\
\hline Health center & 495 & 56 & $53.01-59.56$ \\
\hline Health post & 383 & 43.32 & $39.77-46.30$ \\
\hline Health hut & 6 & 0.68 & $0.31-1.48$ \\
\hline \multicolumn{4}{|c|}{ Distance between residency } \\
\hline More than $5 \mathrm{Kms}$ & 683 & 77.26 & $74.92-80.42$ \\
\hline Less than $5 \mathrm{Kms}$ & 201 & 22.74 & $19.58-25.08$ \\
\hline \multicolumn{4}{|l|}{ Means of transport } \\
\hline Walk & 604 & 68.33 & $65.42-71.54$ \\
\hline Bicycle & 29 & 3.28 & $2.02-4.29$ \\
\hline Motorbike & 118 & 13.35 & $11.30-15.80$ \\
\hline Car & 128 & 14.48 & $12.36-17.01$ \\
\hline Pirogue & & 0.56 & $0.24-1.32$ \\
\hline \multicolumn{4}{|l|}{ Mean time } \\
\hline Less than $30 \mathrm{mn}$ & 617 & 69.80 & $66.77-72.81$ \\
\hline More than $30 \mathrm{mn}$ & 267 & 30.20 & $27.19-33.23$ \\
\hline
\end{tabular}


Table 4. Distribution of surveyed women by socio-professional characteristics in October 2018 in Kédougou Health District.

\begin{tabular}{|c|c|c|c|}
\hline $\begin{array}{c}\text { Socio-cultural } \\
\text { accessibility factors }\end{array}$ & $\begin{array}{l}\text { Absolute frequency } \\
\qquad(\mathrm{n}=884)\end{array}$ & $\begin{array}{c}\text { Relative } \\
\text { frequency (\%) }\end{array}$ & $\begin{array}{c}\text { Interval of } \\
\text { confidence (95\%) }\end{array}$ \\
\hline \multicolumn{4}{|l|}{$\begin{array}{c}\text { Decision-maker for } \\
\text { ANC onset }\end{array}$} \\
\hline Women & 265 & 29.98 & $27.14-33.19$ \\
\hline Mother-in-law & 51 & 5.77 & $4.43-7.53$ \\
\hline Spouse & 535 & 60.52 & $57.46-63.90$ \\
\hline Others & 33 & 3.73 & $2.40-4.82$ \\
\hline \multicolumn{4}{|l|}{$\begin{array}{l}\text { Provision provider } \\
\text { profile for ANC }\end{array}$} \\
\hline Female & 655 & 74.09 & $71.88-77.62$ \\
\hline Male & 37 & 4.19 & $2.22-4.59$ \\
\hline Neutral & 192 & 21.72 & $19.33-24.80$ \\
\hline \multicolumn{4}{|l|}{ ANC awareness } \\
\hline Yes & 336 & 38.01 & $34.87-41.25$ \\
\hline No & 548 & 61.99 & $58.73-65.13$ \\
\hline \multicolumn{4}{|l|}{$\begin{array}{l}\text { Relatives' advice } \\
\text { for early ANCs }\end{array}$} \\
\hline Yes & 784 & 88.69 & $86.31-90.51$ \\
\hline No & 100 & 11.31 & $9.29-13.45$ \\
\hline
\end{tabular}

\section{+ Factors related to health structures}

The majority of women are unsatisfied with the structure welcoming conditions. The rate of satisfied women is $26.36 \%$ for reception and $47.17 \%$ for waiting time. However, $69.12 \%$ of women are satisfied with the provided care.

Among 783 women, $88.57 \%$, the relatives were in favour of an early start for ANC.

The distribution of the women surveyed according to accessibility factors related to health facilities is summarized in Table 4.

\section{+ Completion}

The dependent variable in our study is ANC completion, which is the achievement of four standard ANCs during pregnancy. The rate of ANC completion in our sample is $37 \%$ accounting for 327 women. The majority of women, $63 \%$ of the sample corresponding to 557, did not complete ANC (Figure 1).

The figure summarizes the distribution of the sample according to the number of completed ANCs. 


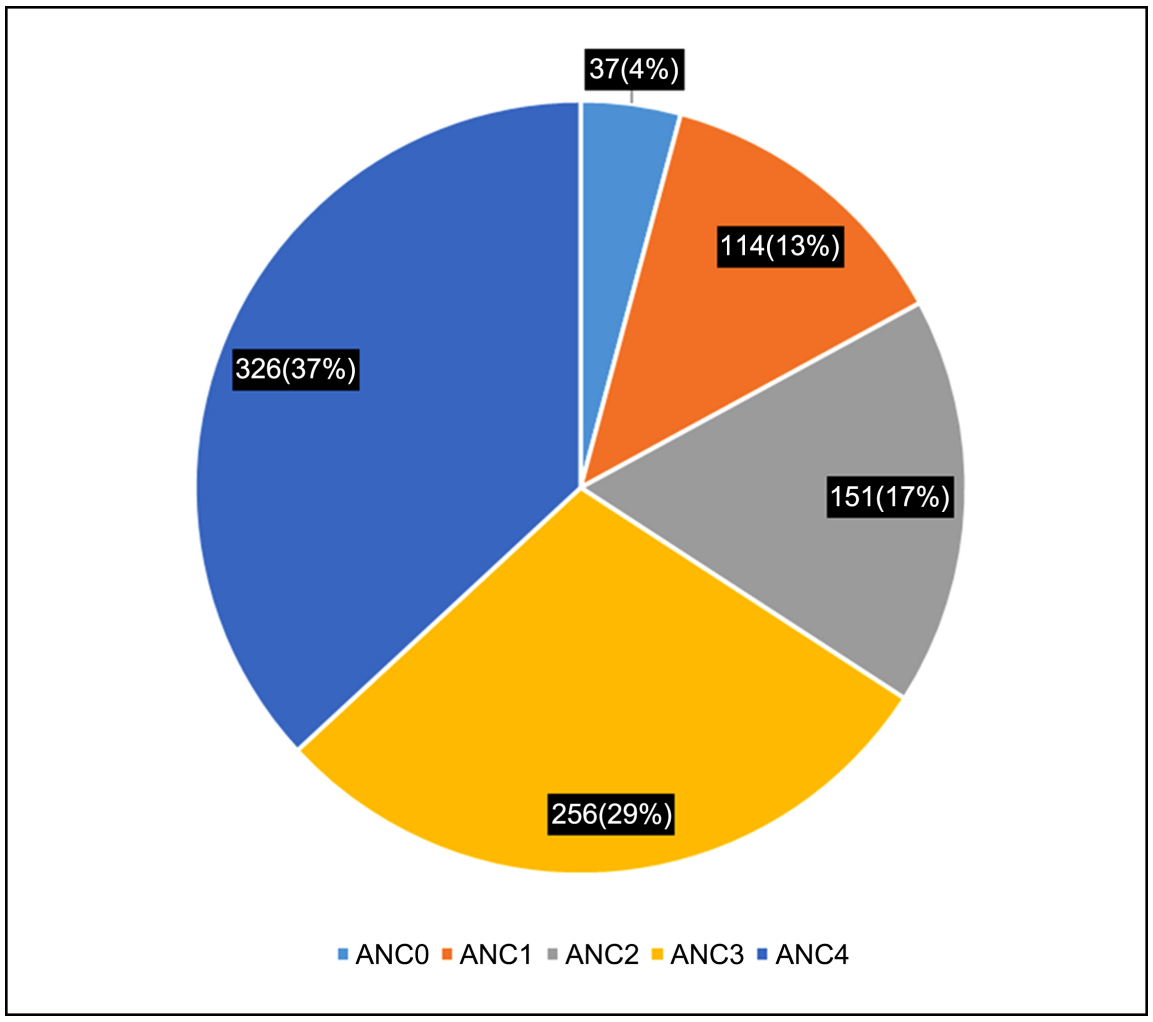

Figure 1. Distribution of women surveyed according to the number of ANC carried out in October 2017 in the Kédougou health district $(\mathrm{N}=884)$.

\subsection{Analytical Study}

\section{+ Personal Factors influence on ANC Completion Rate}

- Completion by age group

The ANC completion rate for women aged 25 years and more is $37.5 \%$, higher than the rate for women under 25 years of age, which is $36.7 \%$. This difference is not statistically significant (Table 5).

\section{- ANCs completion according to marital status}

The completion rate accounts for $37.9 \%$ for married women and $20.8 \%$ for unmarried women. This difference is statistically significant. Marital status influences completion. Married women are 2.3 times more likely to complete ANC than unmarried women (Table 6).

\section{- Completion according to the gestity}

The completion rate for women experiencing less than 4 pregnancies $(38.5 \%)$ is higher than the completion rate for women with 4 or more pregnancies (33.5\%). However, this difference is not statistically significant. Gestity does not determine completion (Table 7).

\section{- Completion according to women's education}

The proportion of educated women who completed their ANC (40.6\%) is higher than the proportion of uneducated women who completed their ANC (26.9\%), which is statistically significant. Educated women are 1.8 times more likely to complete their ANC than uneducated women (Table 8). 
Table 5. Distribution of respondents according to ANC completion and age.

\begin{tabular}{|c|c|c|c|}
\hline \multirow[b]{2}{*}{ Age group } & \multicolumn{2}{|c|}{ Completion } & \multirow[b]{2}{*}{ Total } \\
\hline & $\begin{array}{c}\text { Yes } \\
\text { N (\%) }\end{array}$ & $\begin{array}{c}\text { No } \\
\text { N (\%) }\end{array}$ & \\
\hline Less than 25 years & $\begin{array}{c}194 \\
(36.7)\end{array}$ & $\begin{array}{c}335 \\
(63.3)\end{array}$ & 529 \\
\hline 25 years and more & $\begin{array}{c}133 \\
(37.5)\end{array}$ & $\begin{array}{c}222 \\
(62.5)\end{array}$ & 355 \\
\hline Total & 327 & 557 & 884 \\
\hline
\end{tabular}

Non-corrected Chi2 $=0.0571 ; \mathrm{p}=0.8110647349$.

Table 6. Distribution of respondents according to ANC completion and marital status.

\begin{tabular}{|c|c|c|c|}
\hline \multirow{3}{*}{ Marital status } & \multicolumn{2}{|c|}{ Completion } & \multirow{3}{*}{ Total } \\
\hline & Yes & No & \\
\hline & $\mathrm{N}(\%)$ & N (\%) & \\
\hline \multirow{2}{*}{ Married } & 317 & 519 & \multirow{2}{*}{836} \\
\hline & $(37.9)$ & $(62.1)$ & \\
\hline \multirow{2}{*}{ Unmarried } & 10 & 38 & \multirow{2}{*}{48} \\
\hline & $(20.8)$ & $(79.2)$ & \\
\hline Total & 327 & 557 & 884 \\
\hline
\end{tabular}

Non-corrected Chi2 $=5.6852 ; \mathrm{p}=0.0171088865 ; \mathrm{OR}=2.32 ; \mathrm{CI}[1.1-4.7]$.

Table 7. Distribution of respondents by ANC completion and parity.

\begin{tabular}{|c|c|c|c|}
\hline \multirow[b]{2}{*}{ Gestity } & \multicolumn{2}{|c|}{ Completion } & \multirow[b]{2}{*}{ Total } \\
\hline & $\begin{array}{c}\text { Yes } \\
\text { N (\%) }\end{array}$ & $\begin{array}{c}\text { No } \\
\text { N (\%) }\end{array}$ & \\
\hline Less than 4 pregnancies & $\begin{array}{c}339 \\
(38.5)\end{array}$ & $\begin{array}{c}382 \\
(61.5)\end{array}$ & 621 \\
\hline 4 pregnancies and more & $\begin{array}{c}88 \\
(33.5)\end{array}$ & $\begin{array}{c}175 \\
(66.5)\end{array}$ & 263 \\
\hline Total & 327 & 557 & 884 \\
\hline
\end{tabular}

Non-corrected Chi2 $=2.0025 ; \mathrm{p}=0.1570352535$.

Table 8. Distribution of respondents according to ANC completion and women's education.

\begin{tabular}{|c|c|c|c|}
\hline \multirow[b]{2}{*}{ Educated women } & \multicolumn{2}{|c|}{ Completion } & \multirow[b]{2}{*}{ Total } \\
\hline & $\begin{array}{c}\text { Yes } \\
\text { N (\%) }\end{array}$ & $\begin{array}{c}\text { No } \\
\text { N (\%) }\end{array}$ & \\
\hline Yes & $\begin{array}{c}264 \\
(40.6)\end{array}$ & $\begin{array}{c}386 \\
(59.4)\end{array}$ & 650 \\
\hline No & $\begin{array}{c}63 \\
(26.9)\end{array}$ & $\begin{array}{c}171 \\
(73.1)\end{array}$ & 234 \\
\hline Total & 327 & 557 & 884 \\
\hline
\end{tabular}

Non-corrected Chi2 = 13.8399; $\mathrm{p}=0.0001990676 ; \mathrm{OR}=1.8 ; \mathrm{CI}[1.3-2.6]$. 


\section{- Completion according to the Spouse's instruction}

Married women with educated husbands have an ANC completion rate of $38.8 \%$. This rate is higher than that of women married to uneducated men $30.6 \%$. This difference is statistically significant. Women with educated husbands are 1.4 times more likely to complete their ANC than women with uneducated husbands. The education of spouses is an ANC completion rate determinant (Table 9).

+ Influence of accessibility factors on ANC completion rate.

- Affordability factors

\& Completion according to the monthly income of women

The completion rate for women with a monthly income of CFA 50,000 or more is higher than for those with a monthly income of less than CFA 50,000, corresponding to $44.3 \%$ and $33.3 \%$ respectively. This difference is statistically significant. Women with a monthly income above 50,000 are 1.6 times more likely to complete than those with a monthly income below 50,000 (Table 10).

\section{Completion according to ANC Cost}

The completion rate among women who rated the cost of ANC as affordable, representing $44.3 \%$, is higher than the completion rate among those who rated the cost of ANC as unaffordable, 33.3\%. This difference is statistically significant $(\mathrm{p}=0.032)$. The cost of ANC influenced completion among the women surveyed. Women who found the cost of ANC affordable were 1.4 times more likely to complete their ANC than those who found the cost of ANC unaffordable (Table 11).

- Geographic accessibility factors

* Completion according to the distance between the place of residence and the place of ANCs performance

Among women who were close to their site for ANC, $43.3 \%$ completed their ANC compared to $35.1 \%$ for women living far away. This difference is statistically significant. Women who were close to their ANC site were 1.4 times more likely to complete their ANC than those living far away. Distance is a determinant of ANC completion (Table 12).

○ Socio-cultural factors

Table 9. Distribution of respondents by completion of ANCs and spouse's education.

\begin{tabular}{|c|c|c|c|}
\hline \multirow[b]{2}{*}{ Educated spouse } & \multicolumn{2}{|c|}{ Completion } & \multirow[b]{2}{*}{ Total } \\
\hline & $\begin{array}{c}\text { Yes } \\
\text { N (\%) }\end{array}$ & $\begin{array}{c}\text { No } \\
\text { N (\%) }\end{array}$ & \\
\hline Yes & $\begin{array}{c}267 \\
(38.8)\end{array}$ & $\begin{array}{c}421 \\
(61.2)\end{array}$ & 688 \\
\hline No & $\begin{array}{c}60 \\
(30.6)\end{array}$ & $\begin{array}{c}136 \\
(69.4)\end{array}$ & 196 \\
\hline Total & 327 & 557 & 884 \\
\hline
\end{tabular}

Non-corrected Chi2 $=4.3963 ; \mathrm{p}=0.0360171537 ; \mathrm{OR}=1.4$; CI $[1.0-2.0]$. 
Table 10. Distribution of respondents according to ANC completion and women's monthly income.

\begin{tabular}{cccc}
\hline \multirow{2}{*}{$\begin{array}{c}\text { Monthly income } \\
\geq 50,000\end{array}$} & Yes & \multirow{2}{*}{ Total } \\
\cline { 2 - 3 } & $\mathrm{N}(\%)$ & $\mathrm{No}$ & \\
\hline Yes & 132 & 166 & 298 \\
& $(44.3)$ & $(55.7)$ & \\
No & 195 & 391 & 586 \\
Total & $(33.3)$ & $(66.7)$ & 884 \\
\hline
\end{tabular}

Non-corrected Chi2 $=10.2905 ; \mathrm{p}=0.0013371792 ; \mathrm{OR}=1.6$; CI $[1.2-2.1]$.

Table 11. Distribution of respondents according to ANC completion and cost.

\begin{tabular}{|c|c|c|c|}
\hline \multirow{2}{*}{ Affordable ANC cost } & \multicolumn{2}{|c|}{ Completion } & \multirow[b]{2}{*}{ Tota } \\
\hline & $\begin{array}{c}\text { Yes } \\
\text { N (\%) }\end{array}$ & $\begin{array}{c}\text { No } \\
\text { N (\%) }\end{array}$ & \\
\hline Yes & $\begin{array}{c}232 \\
(44.3)\end{array}$ & $\begin{array}{c}356 \\
(55.7)\end{array}$ & 588 \\
\hline No & $\begin{array}{c}95 \\
(33.3)\end{array}$ & $\begin{array}{c}201 \\
(66.7)\end{array}$ & 296 \\
\hline Total & 327 & 557 & 884 \\
\hline
\end{tabular}

Non-corrected Chi2 $=4.5774 ; \mathrm{p}=0.0323972769 ; \mathrm{OR}=1.4 ; \mathrm{CI}[1.02-1.85]$.

Table 12. Distribution of respondents according to ANC completion and distance from home to ANC provision site.

\begin{tabular}{|c|c|c|c|}
\hline \multirow{2}{*}{$\begin{array}{l}\text { Distance from the } \\
\text { structure } \geq 5 \mathrm{Km}\end{array}$} & \multicolumn{2}{|c|}{ Completion } & \multirow[b]{2}{*}{ Total } \\
\hline & $\begin{array}{c}\text { Yes } \\
\text { N (\%) }\end{array}$ & $\begin{array}{c}\text { No } \\
\text { N (\%) }\end{array}$ & \\
\hline Yes & $\begin{array}{c}87 \\
(43.3)\end{array}$ & $\begin{array}{c}114 \\
(56.7)\end{array}$ & 201 \\
\hline No & $\begin{array}{c}240 \\
(53.1)\end{array}$ & $\begin{array}{c}443 \\
(649)\end{array}$ & 683 \\
\hline Total & 327 & 557 & 884 \\
\hline
\end{tabular}

Non-corrected Chi2 $=4.4197 ; \mathrm{p}=0.0355260575 ; \mathrm{OR}=1.4 ; \mathrm{CI}[1.02-1.94]$.

\section{Acceptance of early ANCs by the relatives}

\section{ANC decision-maker}

The completion rate for women who have already received ANC information is $51.2 \%$. This is significantly higher than those who have not received any information on ANC (28.3\%). This statistically significant difference with a $\mathrm{P}=0.000000$ shows that women's knowledge of ANC influences their completion. Women who received information about ANC were 2.6 times more likely to complete their ANC than those who received no information about ANC (Tables 13-15). 
Table 13. Distribution of respondents according to ANCs completion and acceptance of early ANCs by their relatives.

\begin{tabular}{cccc}
\hline \multirow{2}{*}{$\begin{array}{c}\text { The relatives accept } \\
\text { early ANC }\end{array}$} & \multicolumn{2}{c}{ Completion } & \multirow{2}{*}{ Total } \\
\cline { 2 - 3 } & $\mathrm{N}(\%)$ & No \\
N (\%) & \\
Yes & 298 & 487 & 785 \\
& $(38.0)$ & $(62)$ & \\
No & 29 & 70 & \\
& $(29.3)$ & $(70.7)$ & 894 \\
\hline
\end{tabular}

Non-corrected Chi2 $=2.8345 ; \mathrm{p}=0.0922591014$.

Table 14. ANC completion according to the decision-maker.

\begin{tabular}{|c|c|c|c|}
\hline \multirow[b]{2}{*}{$\begin{array}{l}\text { Women decide for } \\
\text { ANC onset }\end{array}$} & \multicolumn{2}{|c|}{ Completion } & \multirow[b]{2}{*}{ Total } \\
\hline & $\begin{array}{c}\text { Yes } \\
\mathrm{N}(\%)\end{array}$ & $\begin{array}{c}\text { No } \\
\text { N (\%) }\end{array}$ & \\
\hline Yes & $\begin{array}{c}103 \\
(38.9)\end{array}$ & $\begin{array}{c}162 \\
(61.1)\end{array}$ & 265 \\
\hline No & $\begin{array}{c}224 \\
(36.2)\end{array}$ & $\begin{array}{c}395 \\
(63.2)\end{array}$ & 619 \\
\hline Total & 327 & 557 & 884 \\
\hline
\end{tabular}

Non-corrected Chi $2=0.5720 ; \mathrm{p}=0.4494497628$.

Table 15. Completion according to ANC information level.

\begin{tabular}{|c|c|c|c|}
\hline \multirow{2}{*}{$\begin{array}{l}\text { Women decide for } \\
\text { ANC onset }\end{array}$} & \multicolumn{2}{|c|}{ Completion } & \multirow[b]{2}{*}{ Total } \\
\hline & $\begin{array}{c}\text { Yes } \\
\text { N (\%) }\end{array}$ & $\begin{array}{c}\text { No } \\
\text { N (\%) }\end{array}$ & \\
\hline Yes & $\begin{array}{c}172 \\
(51.2)\end{array}$ & $\begin{array}{c}164 \\
(48.8)\end{array}$ & 336 \\
\hline No & $\begin{array}{c}155 \\
(28.3)\end{array}$ & $\begin{array}{c}393 \\
(71.7)\end{array}$ & 548 \\
\hline Total & 327 & 557 & 884 \\
\hline
\end{tabular}

Non-corrected Chi2 = 46.8878; $\mathrm{p}=0.00000000 ;$ OR $=2.6$; CI $[2-3.5]$.

+ Influence of factors related to health structures

- Completion according to the welcoming

The proportion of women who have completed their ANC among those satisfied with the reception in the health facilities is $39.8 \%$ against $29.2 \%$ for those not satisfied with the reception. This difference is statistically significant. Clients satisfied with the reception are 1.6 times more likely to complete their ANC than 
those unsatisfied with the reception (Table 16).

\section{- Completion within the waiting period}

Among women who are satisfied with the waiting time $40.9 \%$ completed their ANC compared to $32.6 \%$ for those who are not satisfied. This difference is statistically significant. Women who were satisfied with their waiting time were 1.4 times more likely to complete their ANC than those who were not (Table 17).

\section{- Completion according to confidentiality}

The completion rate among women satisfied with confidentiality was 37\% compared to $37.2 \%$ for those not satisfied. This difference is not statistically significant. Satisfaction with confidentiality does not affect the completion rate (Table 18).

\section{- Completion according to the management}

The completion rate among women satisfied with their care is $44.5 \%$ against $20.2 \%$ for those not satisfied. This difference is statistically significant. Satisfaction with care influences the completion rate. Women who are satisfied with care have 3.2 more chances of completing their ANC than those who are unsatisfied with care (Table 19).

Table 16. Distribution of respondents according to ANCs completion and satisfaction with reception.

\begin{tabular}{|c|c|c|c|}
\hline \multirow[b]{2}{*}{ Satisfactory reception } & \multicolumn{2}{|c|}{ Completion } & \multirow[b]{2}{*}{ Total } \\
\hline & $\begin{array}{c}\text { Yes } \\
\text { N (\%) }\end{array}$ & $\begin{array}{c}\text { No } \\
\text { N (\%) }\end{array}$ & \\
\hline Yes & $\begin{array}{c}259 \\
(39.8)\end{array}$ & $\begin{array}{c}392 \\
(60.2)\end{array}$ & 651 \\
\hline No & $\begin{array}{c}68 \\
(29.2)\end{array}$ & $\begin{array}{c}165 \\
(70.8)\end{array}$ & 233 \\
\hline Total & 327 & 557 & 884 \\
\hline
\end{tabular}

Non-corrected Chi2 $=8.2724 ; \mathrm{p}=0.0040252706 ; \mathrm{OR}=1.6 ; \mathrm{CI}[1.2-2.2]$.

Table 17. Distribution of respondents according to ANC completion and satisfaction with waiting time.

\begin{tabular}{cccc}
\hline \multirow{2}{*}{$\begin{array}{c}\text { Satisfaction with } \\
\text { waiting time }\end{array}$} & Yes & Tompletion & \\
\cline { 2 - 3 } & $\mathrm{N}(\%)$ & $\mathrm{N}(\%)$ & \\
\hline \multirow{2}{*}{ Yes } & 191 & 276 & 467 \\
& $(40.9)$ & $(59.1)$ & \\
No & 136 & 281 & 417 \\
Total & $(32.6)$ & $(67.4)$ & \\
& 327 & 557 & 884 \\
\hline
\end{tabular}

Non-corrected Chi2 $=6.4884 ; \mathrm{p}=0.0108583669 ; \mathrm{OR}=1.4$; CI [1.1 - 1.9]. 
Table 18. Distribution of respondents according to ANC completion and satisfaction with confidentiality.

\begin{tabular}{cccc}
\hline \multirow{2}{*}{$\begin{array}{c}\text { Confidentiality } \\
\text { satisfaction }\end{array}$} & \multicolumn{2}{c}{ Completion } & \multirow{2}{*}{ Total } \\
\cline { 2 - 3 } & $\mathrm{N}(\%)$ & $\mathrm{No}$ & \\
\hline \multirow{2}{*}{ Yes } & 285 & $\mathrm{~N}(\%)$ & 786 \\
& $(37)$ & $(63)$ & \\
No & 42 & 71 & 113 \\
Total & $(37.2)$ & $(62.8)$ & 884 \\
\hline
\end{tabular}

Non-corrected Chi2 $=0.0017 ; \mathrm{p}=0.9666769102 ; \mathrm{OR}=0.99 ; \mathrm{CI}[0.6-1.5]$.

Table 19. Distribution of respondents according to completion ANCs and satisfaction with care.

\begin{tabular}{|c|c|c|c|}
\hline \multirow[b]{2}{*}{ Satisfaction with care } & \multicolumn{2}{|c|}{ Completion } & \multirow[b]{2}{*}{ Total } \\
\hline & $\begin{array}{c}\text { Yes } \\
\text { N (\%) }\end{array}$ & $\begin{array}{c}\text { No } \\
\text { N (\%) }\end{array}$ & \\
\hline Yes & $\begin{array}{c}272 \\
(44.5)\end{array}$ & $\begin{array}{c}339 \\
(55.5)\end{array}$ & 611 \\
\hline No & $\begin{array}{c}55 \\
(20.2)\end{array}$ & $\begin{array}{c}218 \\
(79.8)\end{array}$ & 273 \\
\hline Total & 327 & 557 & 884 \\
\hline
\end{tabular}

Non-corrected Chi2 $=48.0826 ; \mathrm{p}=0.000000000 ; \mathrm{OR}=3.2 ; \mathrm{CI}[2.3-4.4]$.

\section{Discussion}

The limits of this study are above all the weakness of its cohort.

Pregnancy complications and its consequences are the world's leading cause of morbidity, disability and mortality among women of reproductive age (WRA). Good monitoring of pregnancy through regular and standard ANC would prevent many pregnancy-related complications and reduce maternal mortality. Indeed, countless pregnancy-related factors can be detected during ANCs, and the earlier and more complete the ANC is performed, the better.

The purpose of our study is to outline the determinants of the ANC completion rate among women who gave birth during the 12 months preceding the study onset in Kedougou Health District. The study involved a sample of 884 women who were interviewed from September 18 to October 20, 2018. It allowed us:

O on the one hand to determine the ANC completion rate,

o on the other hand, to assess personal factors, accessibility factors, factors related to health structures, but also to see if there is a link between these factors and the completion of ANC.

Out of the 884 women surveyed, 327 completed 4 ANCs according to standards, corresponding to a completion rate of $37 \%$. 
The main factors were related to socio-demographic characteristics, financial and geographical accessibility and health structures

\section{+ Completion of antenatal care}

In order to be completed, therefore to be effective, ANC must be started early (first trimester of pregnancy) but also fully performed. The proportion of women in our sample who have completed their ANC is $37 \%$. This result is compliant with those reported by Faye A in a study conducted in Gossas [4] and Tall Dia in Kolda [5] where the completion rates were $35 \%$ and $39 \%$ respectively. However, this rate is lower than the data in the 2017 annual report of Kedougou Medical Region (KMR) [6] 41\% and the 2017 HDS [7]. A study conducted in Sedhiou health district argued a completion rate of 50\% [6], while a completion rate of $67.5 \%$ was reported by a study conducted in the department of Tijounine in Mauritania.

The difference noted in relation to the data in the 2017 annual report of the KMR could be explained by the method of calculation used.

\section{+ Influence of socio-demographic factors}

ANCs Completion requires completion of the first (CPN1) early in pregnancy. The number of ANCs currently recommended in Senegal is four, one per trimester and one in the last month of pregnancy. The fourth ANC allows a delivery prognosis [8]. Thus, a delay in ANC1 is a limiting factor in the proper monitoring of pregnancy [9]. The proportion of women with early first ANC (first trimester) was $55.2 \%$ in our study. This result is close to that found by the EDSV [10] which showed that in nearly 3 out of 5 cases (59\%) the first visit were performed during the first 3 months of pregnancy. Ndiaye P [9] argued a lower proportion in their study where CPN1 was early in only $32 \%$ of cases. In Sedhiou, in a study conducted in 2016, the rate of women who experienced CPN1 first trimester was $74.6 \%$ [11].

Our definition of completion being the achievement of four ANCs according to standards (qualitatively and in a timely manner), the ANC1 performance in the first trimester of pregnancy is a prerequisite for any woman. This did not allow us to set the statistical relationship between ANC precocity and ANC completion in our study. However, the study conducted in Sedhiou outlined that women who started ANC in the first trimester were 5.6 times more likely to complete their ANC than those who started late [11]. INSAE studies have also shown that women who performed their first ANC in the second trimester and those who performed it in the third trimester are 5 times and 29.76 times more likely to have irregular ANC than their counterparts who performed their ANC1 in the first trimester of pregnancy, respectively [12]. The number of ANCs performed throughout the pregnancy depends on the stage of pregnancy at the first ANC.

As a result, the woman consulting at the end of her pregnancy can no longer comply with the ANC schedule, nor receive all the care required. The achievement of early ANC is linked to the awareness of ANC period and number during 
a pregnancy. Particular emphasis must be placed on raising women awareness in health facilities for a better knowledge of ANC but also at home by the Bajenou Gox and Relays, especially among primigravida who do not yet have a great pregnancy experience.

Women's education influenced the completion of ANC ( $p=0.00019)$. Educated women were 1.8 times more likely to complete ANC than uneducated women. A similar result was found by YEHDI studies conducted in 2011 ( $\mathrm{p}=$ 0.078) [3] [13].

A high school enrolment rate would increase ANC completion.

Husbands' education also influences the ANC completion rate ( $\mathrm{p}$ inferior to 0.05 ) Women whose husbands are educated are 1.4 times more likely to complete ANC than their wives. In the study performed in Sedhiou, it was found that women with educated husbands were 11 times more likely to complete their ANC. Education leads to a better understanding and adherence to the timing of ANCs.

\section{+ Influence of accessibility factors}

Our study shows that women's income level is a key determinant in the completion of ANCs. Women with incomes above 50,000 CFA completed their ANCs more than those with incomes below 50,000 CFA. In addition, women who found the cost of ANC affordable were 1.4 times more likely to complete their ANC in our study. In Sedhiou, they found that they were three times more likely to achieve.

Several other studies have shown the role of the economic level on the use of health services for antenatal care [2] [14] [15] [16]. It helps meet the needs and access to facilities in case of suffering. Wilkinson and Marmot, in the report considering the social health determinants showed the role of income on the populations health status. This situation is found among the poor as well as the rich. Reducing inequalities is a key point to solving health problems. This requires the involvement of all actors, particularly political ones.

In our study, both geographical inaccessibility of the structures and economic inaccessibility affect the completion. In fact, women who are close (less than 5 $\mathrm{km}$ ) to their ANC site were 1.4 times more likely to have 4 ANCs than women further away (more than $5 \mathrm{~km}$ ) (p inf. 0.005). Several studies have shown that proximity is a key determinant of ANC completion [5] [17] [18]. Problems related to geographical accessibility have been greatly reduced by advanced and mobile strategies, but these are scarce by the lack of human resources.

\section{+ Influence of factors related to health structures}

The reception of consultants by health providers contributed to ANCs completion. Our study showed that clients who were well received were 5.8 times more likely to complete their ANC than those who were poorly received (p. inf. 0.001). Several studies have determined the role of the reception quality compared to regular ANCs: [12] [17].

Elsewhere, $64.3 \%$ were satisfied with waiting time and $98.8 \%$ with confiden- 
tiality. There were statistically significant links between these 2 factors and ANC completion. Studies conducted in Cameroon have shown that women experience long waits, lack of confidentiality and frustration [18].

Strengthening human resources, raising awareness and training health care personnel, and scaling up the facilities will help improve the quality of provided care.

\section{Conclusions}

The purpose of our study was to describe ANC completion determinants in Kedougou Health District in 2017. The results of our survey argued a completion rate of $37 \%$, which is lower than the administrative data (41\%) but below the national target.

The determinants having a statistically most significant link with ANC completion are respectively satisfaction with care and quality of service, women's level of information in relation to ANC, marital status, financial accessibility and distance from the place of ANC.

\section{Conflicts of Interest}

The authors declare no conflicts of interest regarding the publication of this paper.

\section{References}

[1] WHO (2013) World Health Statistics: A Wealth of Information on Global Public Health. 12 p.

[2] National Agency for Statistics and Demography (ANSD). Senegal Multiple Indicator Demographic and Health Survey (EDS-MICS) 20102011.

[3] Kédougou Medical Region: 2016 Annual Report.

[4] National Agency for Statistics and Demography (ANSD) [Senegal] and ICF International (2015) Senegal: Continuous Demographic and Health Survey (EDS-Continue 2014). ANSD and ICF International, Rockville.

[5] Faye, A., Seck, I. and Tall, A.D. (2014) Baseline Study of the "Community Based Maternel and New Born Health (CBMNH). Project in the Kolda Region of Senegal Institut de sante et de développement (ISED) March.

[6] Kédougou Medical Region: 2017 Annual Performance Report.

[7] Ministry of Health (Senegal) (2005) Demographic and Health Survey. $200 \mathrm{p}$.

[8] African Union (2013) Annual Report on the State of Maternal, Newborn and Child Health. 8-36.

[9] Dièye, E.L. (2003) Study of the Factors Determining the Delay in the First Antenatal Consultation in the Health District of Richard-Toll (Senegal). CES Public Health Thesis (Epidemiology, Bio-Statistics and Informatics). ISED, Dakar, No. 11-1-08, 35 p.

[10] Ndiaye, P., Tal-Dia, A., Diediou, A., Dieye, E.H.L. and Dione, D.A. (2005) Sociocultural Determinants of the Delay of the 1st Antenatal Consultation in a Health District in Senegal. Public Health, 17, 531-538.

https://doi.org/10.3917/spub.054.0531 
[11] MBAYE. K: Study of the Factors Determining the Completion of ANC in the Health District of Sedhiou.

[12] INSAE National Institute for Statistics and Economic Analysis (INSAE). Public Scientific Establishment, under the Supervision of the Ministry in Charge of Statistics.

[13] Yehdi, M.S.O.M. (2011) Study of the Socio-Economic and Organizational Determinants of the Low Completion Rate of CPNs in the Department of Tijounine. Master Thesis from Paris Dauphine University (Economics and Management of Public Health in Developing Countries. Ouidah, 19 p.

[14] Magadi, M.A., Madise, N.J. and Rodrigues, R.N. (2000) Frequency and Timing of Antenatal Care in Kenya: Explaining the Variations between Women of Different Communities. Social Science \& Medicine, 51, 551-561.

https://doi.org/10.1016/S0277-9536(99)00495-5

[15] Koné-Péfoyo, A. and Rivard, M. (2006) Poverty and Socio-Cultural Determinants of the Use of Maternal Health Services in Côte d'Ivoire. Revue d Epidémiologie et de Santé Publique, 54, 485-495. https://doi.org/10.1016/S0398-7620(06)76748-7

[16] Abderemane, A., Faye, A. and Seck, T.A.D. (2014) Study of the Determinants of the First Antenatal Consultation in the First Trimester among Women Who Gave Birth during the Period from February 2013 to January 2014 in the Kolda Region. Master's Thesis in Public Health.

[17] Niang, C.I. (2003) Formative Research on Peri-Neonatal Health in the Health District of Kébémer (Senegal). UCAD: ISE, Dakar, 74 p.

[18] Bonono, R.C. and Ongolo-Zogo, P. (2012) Optimize the Use of Prenatal Consultation in Cameroon. Center for the Development of Good Health Practices-Central Hospital, Yaoundé, 14 p. 
Questionnaire: Study of the Determinant Factors Regarding the Completion of ANCs in Kedougou Health District

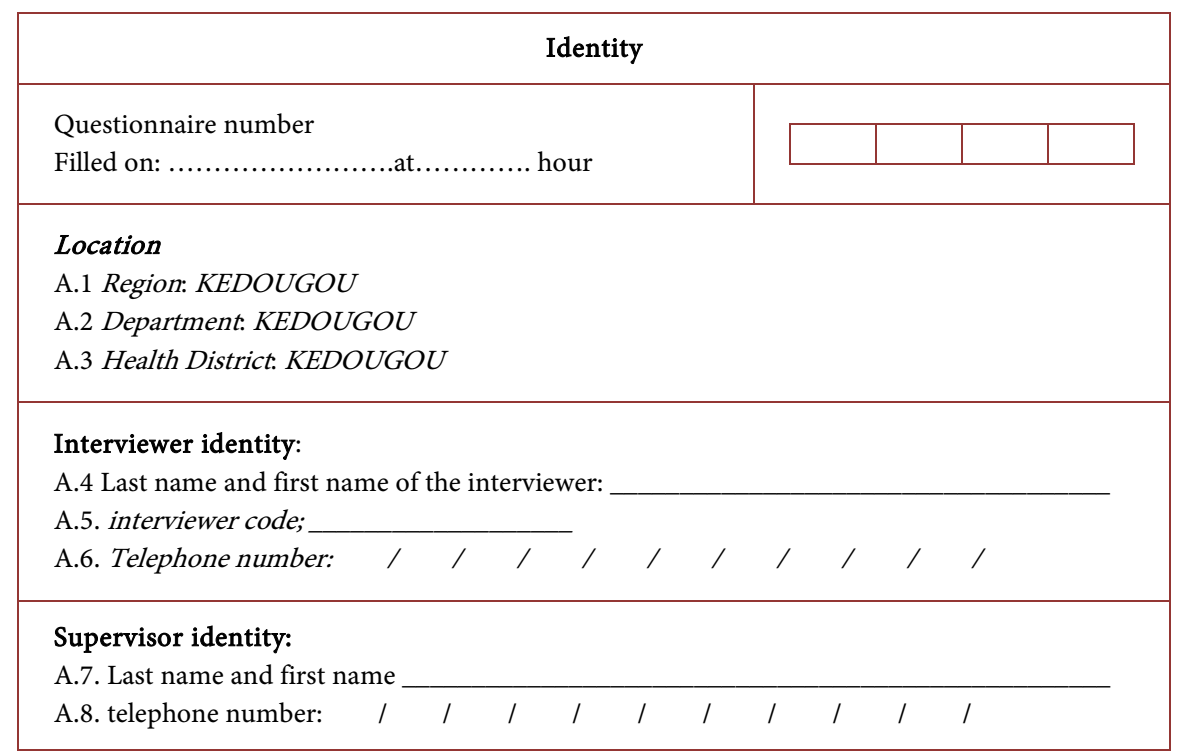

\begin{tabular}{|c|c|c|c|c|}
\hline \multicolumn{5}{|c|}{ Section A: Personnel Factors } \\
\hline 1 & How old are you? & & & \\
\hline 2 & What ethnic group are you? & $\begin{array}{l}\text { Peulh } \square \\
\text { Sérère } \square \\
\text { (to be precised).... }\end{array}$ & $\begin{array}{l}\text { Malinké } \square \\
\text { Wolof } \square \\
\text {................ }\end{array}$ & $\begin{array}{l}\text { Soninké } \square \\
\text { Other } \square\end{array}$ \\
\hline 3 & What is your marital status? & Married $\square$ & Single $\square$ & Widow $\square$ \\
\hline 4 & How many pregnancy have you had? & & & \\
\hline 5 & How many children do you have? & & & \\
\hline 6 & What is your occupation? & $\begin{array}{l}\text { Public official } \square \\
\text { Farmer } \square \\
\text { Other } \square\end{array}$ & $\begin{array}{l}\text { Trader } \square \\
\text { Housekeeper } \\
\text { (to be precised) }\end{array}$ & $\begin{array}{l}\text { Gold digger } \square \\
\text { None } \square \\
\ldots \ldots \ldots \ldots \ldots \ldots\end{array}$ \\
\hline 7 & $\begin{array}{l}\text { What is the occupation of your } \\
\text { husband? }\end{array}$ & $\begin{array}{l}\text { Public official } \square \\
\text { Farmer } \square \\
\text { None } \square \\
\text { (to be precised).... }\end{array}$ & $\begin{array}{l}\text { Trader } \square \\
\text { Shepherd } \square \\
\text { Other } \square \\
\ldots \ldots \ldots \ldots \ldots \ldots\end{array}$ & $\begin{array}{l}\text { Gold digger } \square \\
\text { Worker } \square\end{array}$ \\
\hline 8 & Have you received a notification? & YES $\square$ & NO $\square$ & \\
\hline 9 & $\begin{array}{l}\text { If yes, what kind of notification? } \\
\text { (multiple choice is possible) }\end{array}$ & $\begin{array}{l}\text { Alphabetisation } \square \\
\text { Arabic school } \square\end{array}$ & $\begin{array}{l}\text { Coranic sc } \\
\text { French scl }\end{array}$ & $\begin{array}{l}\mathrm{ool} \square \\
\mathrm{ol} \square\end{array}$ \\
\hline 10 & If French, what is your level? & $\begin{array}{l}\text { Elementary } \square \\
\text { High school } \square\end{array}$ & $\begin{array}{l}\text { Junior hig } \\
\text { Post-grad }\end{array}$ & $\begin{array}{l}\text { school } \square \\
\text { te school } \square\end{array}$ \\
\hline 11 & If Arabic, what is your level? & $\begin{array}{l}\text { Elementary } \square \\
\text { High school } \square\end{array}$ & $\begin{array}{l}\text { Junior hig } \\
\text { Post-grad }\end{array}$ & $\begin{array}{l}\text { school } \square \\
\text { te school } \square\end{array}$ \\
\hline 12 & Did our spouse receive a notification? & YES $\square$ & NO $\square$ & \\
\hline 13 & $\begin{array}{l}\text { If yes, what kind of notification? } \\
\text { (multiple choice is possible) }\end{array}$ & $\begin{array}{l}\text { Alphabetisation } \square \\
\text { Arabic school } \square\end{array}$ & $\begin{array}{l}\text { Coranic sc } \\
\text { French scl }\end{array}$ & $\begin{array}{l}\mathrm{ool} \square \\
\mathrm{ool} \square\end{array}$ \\
\hline
\end{tabular}




\begin{tabular}{|c|c|c|c|c|c|c|}
\hline 14 & If French, what is his level? & \multicolumn{2}{|c|}{$\begin{array}{l}\text { Elementary } \square \\
\text { High school } \square\end{array}$} & \multicolumn{3}{|c|}{$\begin{array}{l}\text { Junior high school } \square \\
\text { Post-graduate school } \square\end{array}$} \\
\hline 15 & If Arabic, what is his level? & \multicolumn{2}{|c|}{$\begin{array}{l}\text { Elementary } \square \\
\text { High school } \square\end{array}$} & \multicolumn{3}{|c|}{$\begin{array}{l}\text { Junior high school } \square \\
\text { Post-graduate school } \square\end{array}$} \\
\hline 16 & $\begin{array}{l}\text { Do you have an ANC notebook that } \\
\text { I can see? }\end{array}$ & \multicolumn{2}{|l|}{ YES $\square$} & \multicolumn{3}{|l|}{ NO $\square$} \\
\hline 17 & $\begin{array}{l}\text { How many ANC did you performed } \\
\text { on your last pregnancy? }\end{array}$ & \multicolumn{5}{|c|}{$0 \square \quad 1 \square \quad 2 \square \quad 3 \square \quad 4 \square \quad 5 \square \quad 6 \square$} \\
\hline \multirow{3}{*}{18} & \multirow{3}{*}{$\begin{array}{l}\text { Which ANC did you undergo during } \\
\text { your last pregnancy? }\end{array}$} & & ANC1 $\square$ & ANC2 $\square$ & ANC3 $\square$ & ANC4 $\square$ \\
\hline & & Period & & & & \\
\hline & & Venue & & & & \\
\hline \multicolumn{7}{|c|}{ Section B: Accessibility Factors } \\
\hline 19 & How much is your monthly income? & \multicolumn{3}{|c|}{$\begin{array}{l}\text { Less than } 47,000 \square \\
50,000 \text { to } 100,000 \square\end{array}$} & \multicolumn{2}{|c|}{$\begin{array}{l}47,000 \text { to } 50,000 \square \\
\text { More than } 100,000 \square\end{array}$} \\
\hline 20 & $\begin{array}{l}\text { How do you find the fees of the ANC } \\
\text { services? }\end{array}$ & \multicolumn{3}{|c|}{$\begin{array}{l}\text { Very accessible } \square \\
\text { Slightly accessible } \square \\
\text { Strongly not accessible } \square\end{array}$} & \multicolumn{2}{|c|}{$\begin{array}{l}\text { Accessible } \square \\
\text { Not accessible } \square\end{array}$} \\
\hline 21 & $\begin{array}{l}\text { Where do you usually perform your } \\
\text { ANC? }\end{array}$ & \multicolumn{3}{|c|}{$\begin{array}{l}\text { Health District } \square \\
\text { health cut } \square\end{array}$} & \multicolumn{2}{|c|}{ health post $\square$} \\
\hline 22 & $\begin{array}{l}\text { How far do you live from the health } \\
\text { district where you perform your } \\
\text { ANC? }\end{array}$ & \multicolumn{5}{|c|}{ Less than $5 \mathrm{Km} \square$} \\
\hline 23 & $\begin{array}{l}\text { What means of transport do you } \\
\text { usually use? }\end{array}$ & \multicolumn{3}{|c|}{$\begin{array}{l}\text { Walk } \square \\
\text { Pirogue } \square\end{array}$} & \multicolumn{2}{|c|}{ Motorbike $\square$} \\
\hline 24 & $\begin{array}{l}\text { How long does it take you to get } \\
\text { there, on average? }\end{array}$ & \multicolumn{5}{|c|}{$\begin{array}{l}\text { Less than } 30 \text { minutes } \square \\
\text { More than } 30 \text { minutes } \square\end{array}$} \\
\hline 25 & $\begin{array}{l}\text { Who makes the decision for you to } \\
\text { begin the ANC? }\end{array}$ & \multicolumn{3}{|c|}{$\begin{array}{l}\text { Oneself } \square \quad \text { Spouse } \square \\
\text { Other } \square \ldots \ldots \ldots \ldots \ldots \ldots \ldots \ldots . \ldots . \ldots . \ldots\end{array}$} & \multicolumn{2}{|c|}{ Mother-in-law $\square$} \\
\hline 26 & $\begin{array}{l}\text { What provider do you wish to be } \\
\text { examined by during your ANC? }\end{array}$ & \multicolumn{2}{|c|}{ Male $\square$} & male $\square$ & \multicolumn{2}{|c|}{ Neutral $\square$} \\
\hline 27 & $\begin{array}{l}\text { Have you ever attended some talks } \\
\text { considering early ANCs? }\end{array}$ & \multicolumn{5}{|l|}{ YES $\square$} \\
\hline 28 & If yes, with who? & \multicolumn{3}{|c|}{$\begin{array}{l}\text { Health care provider } \square \\
\text { Other women } \square\end{array}$} & \multicolumn{2}{|c|}{$\begin{array}{l}\text { ACP } \square \\
\text { Between friends } \square\end{array}$} \\
\hline 29 & $\begin{array}{l}\text { Does your entourage accept to begin } \\
\text { your ANCs early? }\end{array}$ & \multicolumn{5}{|l|}{ Yes $\square$} \\
\hline 30 & If No, why? & \multicolumn{5}{|c|}{$\begin{array}{l}\text { Hide the pregnancy } \square \\
\text { Reduce the expenses related to the pregnancy } \square \\
\text { Afraid of taking medications } \square \\
\text { Other } \square\end{array}$} \\
\hline \multicolumn{7}{|c|}{ Section C: Factors Related to Health Structures } \\
\hline 31 & $\begin{array}{l}\text { How do you find the reception where } \\
\text { you perform your ANCs? }\end{array}$ & \multicolumn{3}{|c|}{$\begin{array}{l}\text { Very satisfied } \square \\
\text { Slightly satisfied } \square \\
\text { Strongly unsatisfied } \square\end{array}$} & \multicolumn{2}{|c|}{$\begin{array}{l}\text { Satisfied } \square \\
\text { Unsatisfied } \square\end{array}$} \\
\hline
\end{tabular}




\begin{tabular}{|l|l|ll|}
\hline 32 & $\begin{array}{l}\text { Are you satisfied with the length of } \\
\text { stay before your consultation time? }\end{array}$ & $\begin{array}{l}\text { Very satisfied } \square \\
\text { Slightly satisfied } \square \\
\text { Strongly unsatisfied } \square\end{array}$ & $\begin{array}{l}\text { Satisfied } \square \\
\text { Unsatisfied } \square\end{array}$ \\
\hline 33 & $\begin{array}{l}\text { Are you satisfied with the } \\
\text { confidentiality? }\end{array}$ & $\begin{array}{l}\text { Very satisfied } \square \\
\text { Slightly satisfied } \square \\
\text { Strongly unsatisfied } \square\end{array}$ & $\begin{array}{l}\text { Satisfied } \square \\
\text { Unsatisfied } \square\end{array}$ \\
\hline 34 & $\begin{array}{l}\text { Are you satisfied with the } \\
\text { management you receive? }\end{array}$ & $\begin{array}{l}\text { Very satisfied } \square \\
\text { Slightly satisfied } \square \\
\text { Strongly unsatisfied } \square\end{array}$ & $\begin{array}{l}\text { Satisfied } \square \\
\text { Unsatisfied } \square\end{array}$ \\
\hline \multicolumn{2}{|l}{ Ending time of the survey } & $-\quad$ - & Hour (s): Minute(s) \\
\hline
\end{tabular}

